Open Access at : http://jurnal.umt.ac.id/index.php/replik/article/view/1441

\title{
ANAMOLI KEWENANGAN: STUDI PENGATURAN JALAN UMUM DALAM KEGIATAN USAHA PERTAMBANGAN MINERAL DAN BATUBARA DI SUMATERA SELATAN
}

\author{
Ahmad \\ Fakultas Hukum Universitas Muhammadiyah Tangerang \\ Email : ahmad@umt.ac.id
}

\begin{abstract}
Abstrak
Adanya tumpang tindih kewenangan antara pemerintah pusat dengan pemerintah daerah Provinsi Sumatera Selatan terkait dengan kewenangan mengatur penggunaan jalan umum untuk kegiatan pengangkutan batubara telah menjadi hal yang problematik bagi dunia usaha dan menarik untuk diteliti, dikaji secara mendalam agar ditemukan solusi penyelesaian atas adanya anomali kewenangan tersebut sehingga usaha pertambangan khususnya bagi pemegang ijin usaha pertambangan tidak mengalami kerugian karena adanya larangan menggunakan jalan umum untuk kegiatan pengangkutan batubara sebagaimana Peraturan Daerah Provinsi Sumatera Selatan Nomor 5 Tahun 2011 tentang pelaksanaan kegiatan usaha pertambangan mineral dan batubara dan peraturan pelaksananya. Metode penelitian yang digunakan adalah penelitian kepustakaan dan pendekatan kasus. Adapun hasil penelitian yakni adanya larangan menggunakan jalan umum untuk kegiatan pengangkutan batubara oleh pemerintah provinsi Sumatera Selatan bersifat menyeluruh baik jalan nasional maupun jalan provinsi sehingga ketentuan tersebut bertentangan UU 38/2004 yang memberikan kewenangan pemerintah pusat untuk mengaturnya. Padahal UU 4/2009 membolehkan menggunakan sarana prasana umum untuk kegiatan pertambangan, serta adanya larangan dalam perda provinsi Sumsel tersebut bertentangan secara hirarkis sebagaimana yang ditentukan dalam UU 12/2011. Dampak lanjutan karena adanya larangan menggunakan jalan umum adalah dunia usaha dirugikan sehingga mengakibatkan adanya dualisme kewenangan yang tumpang tindih dalam pengaturan jalan padahal secara jelas $U U$ 38/2004 memberikan kewenangan kepada pemerintah pusat untuk mengatur jalan nasional bukan pemerintah provinsi, UU 4/2009 membolehkan untuk menggunakan jalan umum untuk kegiatan pertambangan mineral dan batubara serta secara hirarkis bertentangan dengan ketentuan pembentukan peraturan perundangundangan sehingga berakibat secara hukum, ekonomi maupun jaminan kepastian bagi dunia usaha secara khusus bagi pemegang ijin usaha pertambangan.
\end{abstract}

Kata Kunci: Kewenangan, Jalan, mineral dan batubara, dunia usaha 


\section{PENDAHULUAN}

Jalan merupakan prasarana transportasi darat dalam menunjang perekonomian dan pergerakan barang dan jasa serta syarat mutlak bagi perkembangan dan pembangunan suatu daerah. Jalan memiliki peran dan fungsi utama dalam arus perpindahan orang dan barang dari suatu tempat ke tempat lain, pemerataan hasil-hasil pembangunan antar wilayah, juga memiliki peran penting dalam mempererat hubungan antar daerah serta mempercepat pengembangan wilayah dari keterisolasian dengan daerah lain. Oleh sebab itu, ketersedian sarana transportasi jalan yang baik merupakan syarat mutlak yang harus dipenuhi seluruh wilayah di tanah air. ${ }^{1}$

Hal tersebut diatas sejalan dengan pengertian jalan sebagaimana dirumuskan dalam Pasal 1 angka 3 Peraturan Pemerintah nomor 34 tahun 2006 tentang jalan yang menegaskan, jalan merupakan prasarana transportasi darat yang meliputi segala bagian jalan, termasuk bangunan pelengkap dan perlengkapannya yang diperuntukkan bagi lalu lintas, yang berada pada permukaan tanah, di atas permukaan tanah, di bawah permukaan tanah dan/atau air, serta di atas permukaan air, kecuali jalan kereta api, jalan lori, dan jalan kabel.

Dalam penjelasan umum peraturan pemerintah nomor 34 tahun 2006 tentang jalan menegaskan hal-hal penting mengenai peranan dan fungsi jalan yakni sebagai salah satu prasarana transportasi dalam kehidupan bangsa, kedudukan dan peranan jaringan jalan pada hakikatnya menyangkut hajat hidup orang banyak serta mengendalikan struktur pengembangan wilayah pada tingkat nasional, terutama yang menyangkut pewujudan perkembangan antardaerah yang seimbang dan pemerataan hasil-hasil pembangunan, serta peningkatan pertahanan dan keamanan negara, dalam rangka mewujudkan rencana pembangunan jangka panjang dan rencana pembangunan jangka menengah menuju masyarakat Indonesia yang adil dan makmur berdasarkan Pancasila dan Undang-Undang Dasar 1945.

Dengan kedudukan dan peranan jalan tersebut, negara berhak menguasai jalan. Penyediaan jalan umum oleh negara pada dasarnya dibangun di atas tanah yang dikuasai oleh negara. Bila dibangun di atas tanah hak atas orang, dilaksanakan

${ }^{1}$ Tommy Putra Armada, Analisa Ekonomi Perbaikan Jalan Palembang - Betung Kab. Banyuasin Terhadap Nilai Kerugian Akibat Kemacetan, Jurnal Tehnik Sipil dan Lingkungan, Vol. 2 No. 3, September 2014, hlm. 1 
dengan pengadaan tanah. Dengan hak penguasaan jalan ada pada negara, pemerintah sebagai pemegang kekuasaan pemerintahan negara, mempunyai hak menyelenggarakan jalan secara umum. Penyelenggaraan jalan harus menjamin terselenggaranya peranan jalan yang berdasarkan rencana tata ruang wilayah dengan memperhatikan keterhubungan antarkawasan atau keterhubungan dalam kawasan serta dilakukan secara konsepsional dan menyeluruh.

Penyelenggaraan jalan sebagai salah satu bagian kegiatan dalam mewujudkan prasarana transportasi melibatkan masyarakat dan pemerintah. Sehubungan dengan hal tersebut, setiap usaha penyelenggaraan jalan memerlukan kesepakatan atas pengenalan sasaran pokok yang dilandasi oleh jiwa pengabdian dan tanggung jawab terhadap bangsa dan Negara.

Dalam kaitannya penggunaan jalan untuk kegiatan pertambanganan batubara sebagai salah satu sarana perpindahan hasil tambang dari satu titik ketitik lain juga sangat bergantung kepada ketersediaan dan penggunaan jalan untuk kegiatan pengangkutannya. Batubara merupakan salah satu penyumbang devisa yang cukup besar bagi Negara. Provinsi Sumatera Selatan pada khususnya memiliki potensi besar sebagai produsen Batubara yaitu sekitar $48 \%$ dari Produksi Nasional sehingga dengan potensi ini Provinsi Sumatera Selatan menjadi Lumbung Energi Nasional. Potensi batubara di Sumatera Selatan diangkut melalui sungai dan darat dimana transportasi melalui darat melewati 414,132 $\mathrm{KM}$ ruas jalan nasional $(28,67 \%)$ dari total panjang Jalan Nasional di Provinsi Sumatera Selatan (menurut hasil exercise BBPJN III tahun 2011). ${ }^{2}$

Oleh karena itu kegiatan pertambangan menggunakan sarana dan prasana umum seperti penggunaan jalan sehingga membutuhkan pengaturan baik jalan yang merupakan kewenangan pemerintah pusat maupun jalan yang menjadi kewenangan pemerintah provinsi, kota/kabupaten sehingga batas kewenangan tersebut tidak terjadi tumpang tindih antara kewenangan pemerintah pusat dengan kewenangan pemerintah daerah sehingga adanya larangan yang dilakukan oleh

2 https://balai3.wordpress.com/2011/07/01/alternatif-solusi-permasalahan-angkutanbatubara-di-sumatera-selatan/ 
Pemerintah Daerah Provinsi Sumatera Selatan menggunakan seluruh jalan umum untuk kegiatan pengangkutan batubara telah melampui kewenangannya.

Bahwa pertambangan adalah sebagian atau seluruh tahapan kegiatan dalam rangka penelitian, pengelolaan dan pengusahaan mineral atau batubara yang meliputi penyelidikan umum, eksplorasi, studi kelayakan, konstruksi, penambangan, pengolahan dan pemurnian, pengangkutan dan penjualan, serta kegiatan pascatambang. Demikian juga dengan Mineral adalah senyawa anorganik yang terbentuk di alam, yang memiliki sifat fisik dan kimia tertentu serta susunan kristal teratur atau gabungannya yang membentuk batuan, baik dalam bentuk lepas atau padu. Serta batubara adalah endapan senyawa organik karbonan yang terbentuk secara alamiah dari sisa tumbuh-tumbuhan.

Pertambangan Mineral merupakan pertambangan kumpulan mineral yang berupa bijih atau batuan, di luar panas bumi, minyak dan gas bumi, serta air tanah sedangkan Pertambangan Batubara adalah pertambangan endapan karbon yang terdapat di dalam bumi, termasuk bitumen padat, gambut, dan batuan aspal. Sementara usaha pertambangan adalah kegiatan dalam rangka pengusahaan mineral atau batubara yang meliputi tahapan kegiatan penyelidikan umum, eksplorasi, studi kelayakan, konstruksi, penambangan, pengolahan dan pemurnian, pengangkutan dan penjualan, serta pascatambang.

Pengenalan masalah pokok jalan memberi petunjuk bahwa penyelenggaraan jalan yang konsepsional dan menyeluruh perlu melihat jalan sebagai suatu kesatuan sistem jaringan jalan yang mengikat dan menghubungkan pusat-pusat kegiatan. Dalam hubungan ini dikenal sistem jaringan jalan primer dan sistem jaringan jalan sekunder. Pada setiap sistem jaringan jalan diadakan pengelompokan jalan menurut fungsi, status, dan kelas jalan. Pengelompokan jalan berdasarkan status memberikan kewenangan kepada Pemerintah untuk menyelenggarakan jalan yang mempunyai layanan nasional dan pemerintah daerah untuk menyelenggarakan jalan di wilayahnya sesuai dengan prinsip-prinsip otonomi daerah.

Penegasan tentang hak dan kewajiban pemerintah serta masyarakat menunjukkan bahwa wewenang pemerintah dalam penyelenggaraan jalan dapat dilimpahkan dan/atau diserahkan kepada instansi-instansi di daerah atau diserahkan 
kepada badan usaha atau perorangan. Pelimpahan dan/atau penyerahan wewenang penyelenggaraan jalan tersebut tidak melepas tanggung jawab pemerintah atas penyelenggaraan jalan.

Jalan sebagai salah satu prasarana transportasi yang menyangkut hajat hidup orang banyak, mempunyai fungsi sosial yang sangat penting. Dengan pengertian tersebut wewenang penyelanggaraan jalan wajib dilaksanakan dengan mengutamakan sebesar-besar kepentingan umum. Sehingga pengertian jalan umum yang merupakan jalan yang diperuntukkan bagi lalu lintas umum sebagaimana yang durumuskan dalam undang-undang jalan mempunyai makna dan dapat diimplementasikan.

Maka adanya ketentuan pasal 52 ayat (1) dan (2) Peraturan Daerah Provinsi Sumatera Selatan Nomor 5 Tahun 2011 tentang Kegiatan pertambangan yang mengatur larangan menggunakan jalan umum untuk kegiatan pertambangan dan memberikan dispensasi kepada para pemegang IUP untuk menyiapkan jalan khusus paling lambat 2 (dua) akan tetapi jangka waktu selama dua tahun tersebut dirasa tidak cukup sehingga Gubernur Sumatera Selatan (Alex Nurdin) memberikan dispensasi penggunaan jalan umum sampai dengan 07 November 2018 karena belum tersedianya jalan khusus.

Namun Gubernur terpilih Provonsi Sumatera Selatan (Herman Deru) periode (2018-2013) membuat kebijakan dengan mengeluarkan Peraturan Gubernur Nomor 74 Tahun 2018 tentang Pencabutan Peraturan Gubernur Nomor 23 Tahun 2011 Tentang Tata Cara Pengangkutan Batubara Melalui Jalan Umum sehingga berlaku ketentuan larangan menggunakan jalan umum untuk kegiatan pertambangan sebagaimana ketentuan Pasal 52 ayat (1) dan (2) Peraturan daerah Provinsi Sumatera Selatan Nomor 5 Tahun 2011 tentang Pelaksanaan kegiatan pertambangan batubara.

Dengan adanya keharusan menggunakan jalan khusus untuk kegiatan pertambangan maka jalan khusus yang tersedia hanya jalan khusus yang dikelola oleh PT. Titan Infra Energy maka berlaku mekanisme bisnis to bisnis. Sementara menurut Ketua Asosiasi Pertambangan Batu Bara Sumatera Selatan (APBS) Andi Asmara mengatakan pihaknya menargetkan $120 \mathrm{~km}$ jalan khusus selesai dan beroperasi tahun 2019. Bahkan jalan khusus telah dibangun dalam 2 tahun terakhir. 
Selain jalan khusus, sebenarnya ada juga jalur angkut melalui jalur kereta api. PT KAI belum siap untuk mengangkut batubara milik para penambang Sumsel yang mencapai 3,5 juta ton. Jalan khusus harus ada, jarak tempuh dari tambang menuju pelabuhan cukup jauh dan bisa sampai $200 \mathrm{~km}$. Berbeda dengan tambang di daerah Kalimantan yang paling jauh cuma $40 \mathrm{~km}^{3}$ kenyataan belum tersedianya jalan khusus yang dibangun oleh pemerintah provinsi Sumsel atau berlarut-larut ijin dari berbagai kementerian sehingga menyulitkan pengadaan jalan khusus oleh pengusaha yang telah memliki IUP dan selama ini menggunakan jalan umum untuk kegiatan pengangkutan batubara.

Asosiasi Perusahaan Batubara Indonesia memperkirakan kebijakan penutupan jalan umum untuk angkutan batubara oleh Pemerintah Provinsi Sumatra Selatan yang mulai berlaku berpotensi mengganggu kinerja ekspor dan pasokan ke proyek kelistrikan domestik. Direktur Eksekutif Asosiasi Perusahaan Batubara Indonesia (APBI) Hendra Sinadia mengatakan saat ini jumlah produksi batubara di Sumsel diperkirakan 48.5 juta ton, atau sekitar 10\%-12\% dari total produksi nasional. Adapun volume batubara yang melewati jalan yang aksesnya ditutup oleh pemprov itu diperkirakan sekitar 5.8 juta ton per tahun. Namun, untuk saat ini APBI juga sedang melakukan cross check dan mengonfirmasi anggotanya yang memegang izin usaha pertambangan (IUP) di wilayah itu. Terkait jumlah produksi batubara di Sumsel dan potensi kerugian sehingga berdampak negative dan berpotensi mengganggu ekspor dan pasokan ke proyek kelistrikan domestik. ${ }^{4}$

Industri angkutan batubara di Sumatra Selatan diprediksikan akan merugi Rp 25 miliar-Rp30 miliar per hari dengan kebijakan penutupan jalan umum untuk angkutan batu bara oleh Pemerintah Provinsi Sumatra Selatan yang telah dimulai Rabu tanggal 07 November 2018. Sekjen Dewan Pimpinan Pusat Asosiasi Pengusaha Truk Indonesia (Aptrindo) Wisnu. W Pettalolo menilai bahwa kebijakan

3 https://news.detik.com/berita/4291797/pengusaha-di-sumsel-setuju-truk-batu-barawajib-lewat-jalan-khusus, (diakses pada tanggal 27 Desember 2018, Pukul 16.30 wib).

4 https://sumatra.bisnis.com/read/20181109/436/858105/angkutan-batu-bara-sumselbelum-ada-truk-melintas-di-jalan-khusus (diakses pada tanggal 27 Desember 2018, Pukul 16.30 wib). 
itu terburu-buru karena persiapan pemerintah provinsi sangat minim dan mengancam bisnis angkutan truk batubara. ${ }^{5}$

Berdasarkan uraian tersebut diatas maka dalam penelitian ini dapat dirumuskan dua permasalahan sebagai berikut; bagaimana kewenangan pengaturan jalan umum untuk kegiatan pengangkutan batubara di Provinsi Sumsel dan apa implikasi hukum dan ekonominya jika ketentuan perda provinsi Sumsel bertentangan dengan ketentuan dalam undang-undang.

\section{METODELOGI PENELITIAN}

Jenis penelitian ini adalah penelitian pustaka yang sumber datanya diperoleh melalui penelitian terhadap berbagai literatur yang relevan dengan obyek penelitian. Sebagai sebuah penelitian yang menelusuri prinsip dan teori tentang dualism norma peraturan perundang-undangan, maka secara metodologis penelitian ini akan mengkaji norma peraturan daerah provinsi Sumatera Selatan dikaitkan dengan peraturan perundang-undangan yang lebih tinggi.

Adapun tipe penelitian ini adalah deskriptif analitis kualitatif, artinya penelitian dilakukan dengan mendeskripsikan, menganalisis secara kualitatif atas data yang berkaitan dengan obyek penelitian baik dalam hukum positif maupun implementasi untuk menarik kesimpulan sesuai dengan pokok masalahnya.

\section{PEMBAHASAN}

\section{A. Perda Provinsi Sumsel Bertentangan dengan Undang-Undang.}

Pengertian Jalan Umum dan Jalan Khusus diatur sebagaimana yang diatur Undang-undang Nomor 38 Tahun 2004 tentang Jalan, yang menyatakan: “Jalan umum adalah jalan yang diperuntukkan bagi lalu lintas umum”. Dan “Jalan khusus adalah jalan yang dibangun oleh instansi, badan usaha, perseorangan, atau kelompok masyarakat untuk kepentingan sendiri”.

https://sumatra.bisnis.com/read/20181109/436/858105/angkutan-batu-bara-sumselbelum-ada-truk-melintas-di-jalan-khusus (diakses pada tanggal 27 Desember 2018, Pukul 16.30 wib). 
Berdasarkan ketentuan Pasal 9 ayat (1), ayat (2), ayat (3), ayat (4) dan ayat (5) Undang-Undang Nomor 38 Tahun 2004 tentang Jalan, mengatur sebagai berikut:

1. Jalan umum menurut statusnya dikelompokkan ke dalam jalan nasional, jalan provinsi, jalan kabupaten, jalan kota, dan jalan desa.

2. Jalan nasional sebagaimana dimaksud pada ayat (1) merupakan jalan arteri dan jalan kolektor dalam sistem jaringan jalan primer yang menghubungkan antaribukota provinsi, dan jalan strategis nasional, serta jalan tol.

3. Jalan provinsi sebagaimana dimaksud pada ayat (1) merupakan jalan kolektor dalam sistem jaringan jalan primer yang menghubungkan ibukota provinsi dengan ibukota kabupaten/kota, atau antaribukota kabupaten/kota, dan jalan strategis provinsi.

4. Jalan kabupaten sebagaimana dimaksud pada ayat (1) merupakan jalan lokal dalam sistem jaringan jalan primer yang tidak termasuk pada ayat (2) dan ayat (3), yang menghubungkan ibukota kabupaten dengan ibukota kecamatan, antaribukota kecamatan, ibukota kabupaten dengan pusat kegiatan lokal, antar pusat kegiatan lokal, serta jalan umum dalam sistem jaringan jalan sekunder dalam wilayah kabupaten, dan jalan strategis kabupaten.

5. Jalan kota sebagaimana dimaksud pada ayat (1) adalah jalan umum dalam sistem jaringan jalan sekunder yang menghubungkan antarpusat pelayanan dalam kota, menghubungkan pusat pelayanan dengan persil, menghubungkan antarpersil, serta menghubungkan antarpusat permukiman yang berada di dalam kota.

Demikian juga ketentuan Pasal 14 ayat (1) dan ayat (2) UU No. 38/2004 tersebut menyatakan :

1. Wewenang Pemerintah dalam penyelenggaraan jalan meliputi penyelenggaraan jalan secara umum dan penyelenggaraan jalan nasional 
2. Wewenang penyelenggaraan jalan secara umum dan penyelenggaraan jalan nasional sebagaimana dimaksud pada ayat (1) meliputi pengaturan, pembinaan, pembangunan, dan pengawasan.

Berdasarkan ketentuan tersebut diatas, pengaturan, pembinaan, pembangunan dan pengawasan jalan nasional adalah menjadi wewenang Pemerintah Pusat. Pasal 52 ayat (1) dan ayat (2) Perda Provinsi Sumsel No. 5/2011, Pergub No. 74/2018, SE Gub. No. 540/2018 dan Surat Dishub Provinsi Sumsel No. $551 / 2018$ yang mengatur pemamfaatan dan penggunaan jalan yang berstatus Jalan Nasional, jelas-jelas bertentangan dengan ketentuan Pasal 14 ayat (1) dan ayat (2) Undang-Undang Nomor 38 Tahun 2004 tentang Jalan, yang pada pokoknya menentukan bahwa kewenangan pengaturan Jalan Nasional ada pada Pemerintah Pusat sebagaimana telah diuraikan diatas.

Selain itu berdasarkan Pasal 18 ayat (1) UU No 38/2004, juga menegaskan bahwa pembuatan Peraturan Perundang-Undangan dalam rangka pengaturan jalan umum, haruslah sesuai dengan kewenangan masing-masing tingkat pemerintahan. Ketentuan hukum Pasal 18 ayat (1) UU 38/2004 tersebut menyatakan: "Pengaturan jalan secara umum sebagaimana dimaksud dalam Pasal 17 meliputi; a. pembentukan peraturan perundang-undangan sesuai dengan kewenangannya.

Sementara dalam ketentuan Pasal 121 ayat (1) dan ayat (2) Peraturan Pemerintah RI Nomor 34 Tahun 2006 tentang Jalan, memberikan definisi sebagai berikut:

1. Jalan khusus merupakan jalan yang dibangun dan dipelihara oleh orang atau instansi untuk melayani kepentingan sendiri.

2. Penyelenggaraan jalan khusus sebagaimana dimaksud pada ayat (1) dilaksanakan sesuai dengan pedoman yang ditetapkan menteri.

Penjelasan Pasal 121 ayat (1):

Yang dimaksud dengan "jalan khusus" antara lain jalan perkebunan, jalan pertanian, jalan kehutanan, jalan pertambangan, jalan inspeksi saluran pengairan, jalan sementara pelaksanaan konstruksi, jalan di kawasan pelabuhan, jalan di kawasan industri, jalan di kawasan berikat, dan jalan di kawasan permukiman yang belum diserahkan kepada penyelenggara jalan umum. Yang dimaksud dengan 
"instansi" adalah Pemerintah atau pemerintah daerah selain penyelenggara jalan uтит.

Dengan demikian berdasarkan PP No. 34/2006 tersebut tidak mengatur kewajiban pemegang IUP untuk kegiatan pengangkutan batubara menggunakan jalan khusus tetapi hanya mengatur jenis jalan khusus yang dapat digunakan untuk jalan umum.

Ketentuan Pasal 91 Undang-Undang Nomor 4 Tahun 2009 tentang Mineral dan Batubara mengatur sebagai berikut: "Pemegang IUP dan IUPK dapat memanfaatkan prasarana dan sarana umum untuk keperluan pertambangan setelah memenuhi ketentuan peraturan perundang-undangan”. Berdasarkan ketentuan tersebut, secara tegas menyatakan Pemegang Ijin Usaha Pertambangan dapat memanfaatkan sarana dan prasarana umum (termasuk jalan umum) untuk keperluan pertambangan.

Lebih lanjut UU jalan menentukan mengenai jalan umum merupakan salah satu sarana dan prasarana umum yaitu jalan yang diperuntukan bagi lalu lintas umum. Oleh karena menurut UU No. 4/2009 Pemegang IUP dapat memanfaatkan prasarana dan sarana umum (termasuk jalan umum untuk pengangkutan batubara), sedangkan dalam Pasal 52 ayat (1) dan ayat (2) Perda Provinsi Sumsel No. 5/2011 pemegang IUP wajib menggunakan jalan khusus untuk keperluan pertambangan (pengangkutan batubara), maka terbukti bahwa materi muatan dalam Pasal 52 ayat (1) dan ayat (2) Perda Provinsi Sumsel No. 5/2011 beserta peraturan pelaksanaannya bertentangan dengan Pasal 91 UU 4/2009.

Berdasarkan Pasal 91 UU 4/2009 tersebut, Perda Provinsi Sumsel No. 5/2011 telah mengatur hal yang bertentangan dengan sesuatu yang diperbolehkan berdasarkan ketentuan Undang-Undang. Dalam hal ini Perda Provinsi Sumsel melarang Pemegang IUPK untuk menggunakan fasilitas umum padahal Pasal 91 UU 4/2009 membolehkan para pemegang IUPK untuk menggunakan fasilitas umum dimana jalan adalah salah satu fasilitas umum. Peraturan perundangundangan yang dimaksud dalam Pasal 91 UU 4/2009, harus dimaknai sebagai pelaksanaan peraturan perundang-undangan sebagaimana yang di syaratkan dalam IUPK, bukan berdasarkan Perda Provinsi yang bertentangan dengan UU. Oleh karena itu Perda Provinsi Sumsel No. 5/2011 beserta aturan turunannya yaitu Pergub No. 74/2018, SE Gub. No. 540/2018 dan Surat Dishub Provinsi Sumsel No. 
551/2018 bertentangan dengan Undang-Undang Nomor 38 Tahun 2004 tentang Jalan.

Penggunaan jalan umum untuk kegiatan tambang dan perkebunan maka pemerintah melalui Kementerian Pekerjaan Umum telah mengeluarkan regulasi yaitu Peraturan Menteri Pekerjaan Umum nomor 20/PRT/M/2011 tentang pedoman pemanfaatan dan penggunaan bagian-bagian jalan. Permen PU nomor 20/PRT/M/2011 telah mengatur dan memberikan syarat tertentu yang harus dipenuhi bagi penggunaan jalan umum untuk kegiatan diluar dari peruntukan jalan umum, dan yang berwenang untuk memberikan izin atau dispensasi penggunaan jalan umum yaitu untuk penggunaan jalan nasional harus mendapatkan izin/dispensasi dari Menteri PU yang dalam hal ini didelegasikan kepada Balai Besar Pelaksanaan Jalan nasional, Penggunaan jalan provinsi harus melalui izin/dispensasi gubernur dan penggunaaan jalan kabupaten/kota harus melalui izin/dispensasi Bupati/Walikota. Pemberian izin dan dispensasi ini diberikan setelah terpenuhinya syarat administrasi yaitu mengenai rencana pengangkutan dan perizinan usaha serta adanya jaminan pemeliharaan jalan berupa jaminan bank serta polis asuransi dan setelah dilakukan evaluasi dan peninjauan lapangan oleh pemerintah dengan tetap mempertimbangkan fungsi jalan dan faktor keselamatan pengguna jalan. Pemberian izin atau dispensasi ini diberikan dengan jangka waktu dan dievalusi secara ketat pelaksanaannya. ${ }^{6}$

Demikian juga halnya jika dinilai dari sisi pembentukan Peraturan Perundang-Undangan Pasal 52 ayat (1) dan ayat (2) Perda Provinsi Sumsel No. 5/2011 dan Pergub Provinsi Sumsel No. 74/2018 beserta aturan turunanya tersebut bertentangan dengan Pasal 7 ayat (2) Undang-Undang Nomor 12 Tahun 2011 tentang Pembentukan Peraturan Perundang-Undangan yang menentukan bahwa pembentukan norma peraturan perundang-undangan yang lebih rendah tidak boleh bertentangan dengan peraturan perundang-undangan yang lebih tinggi atau harus sesuai dengan hirarki ("UU No. 12/2011") dalam hal ini norma Perda Provinsi Sumsel tersebut bertentangan dengan peraturan perundang-undangan yang lebih tinggi yaitu UU 38/2004 dan UU 4/2009.

\footnotetext{
${ }^{6}$ https://www.kompasiana.com/andre_darmawan/552c404e6ea834a1328b4580/menjeratperusahaan-tambang-yang-menggunakan-jalan-umum-tanpa-izin, (diakses pada tanggal 02 Januari 2019, Pukul 10.00 wib).
} 
Meskipun dalam perkembangan atas adanya ketentuan perda provinsi Sumsel yang bertentangan dengan norma undang-undang telah dilakukan hukum seperti upaya penyelesaian sengketa peraturan perundang-undangan secara nonlitigasi melalui Kementerian Hukum dan HAM sebagaimana yang ditentukan dalam Peraturan Menteri Hukum dan HAM Nomor 32Tahun 2017 tentang Tata Cara Penyelesaian Sengketa Peraturan Perundang-undangan Melalui Jalur Nonlitigasi serta upaya Hak Uji Materiil di Mahkhamah Agung oleh pihak (PT. Dizamatra Powerindo) yang merasa dirugikan karena adanya ketentuan tersebut tetapi belum ada produk hukum yang dihasilkan oleh kedua lembaga tersebut untuk mengatasi adanya ketentuan perda provinsi yang bertentangan dengan undangundang sehingga kepastian hukum bagi dunia usaha belum dapat dipenuhi.

Perda Provinsi Sumsel No. 5/2011 juga bertentangan dengan asas pembentukan dan asas materi muatan peraturan perundang-undangan yaitu antara lain asas keadilan, kepastian hukum dan asas kepastian dalam berusaha sebagaimana yang diatur dalam ketentuan Pembentukan Peraturan PerundangUndangan. Selain itu Perda Provinsi Sumsel No. 5/2011 dan Pergub Provinsi Sumsel No. 74/2018 beserta aturan turunanya tersebut juga bertentangan dengan kebijakan nasional yang harus memberikan kemudahan dalam investasi, mendukung dunia usaha serta kebijakan nasional memberi kemudahan bagi ekspor yang sangat perlu untuk memperoleh devisa negara dalam menunjang pembangunan nasional.

\section{B. Implikasi Yuridis dan Ekonomi Berlakunya Perda Provinsi Sumsel No.} $05 / 2011$.

Perda Provinsi Sumsel No. 5/2011 dan Pergub Provinsi Sumsel No. $74 / 2018$ serta aturan pelaksananya diberlakukan sehingga kegiatan pengangkutan batubara dilarang melewati jalan umum (wajib menggunakan jalan khusus milik swasta) maka akibat hukumnya sebagai berikut :

1. banyak perusahaan tambang batubara (pemegang IUP) di Provinsi Sumsel akan berhenti beroperasi. Artinya sama halnya dengan Pemerintah Provinsi Sumsel memaksa semua perusahaan tambang batubara melewati jalan khusus milik PT. Titan Infra Energy (PT. Servo Lintas Raya). Sehingga 
Pemerintah Provinsi Sumsel memberikan monopoli kepada PT. Titan Infra Energy (PT. Servo Lintas Raya) karena tidak ada jalan khusus yang lain untuk dilewati oleh para pemegang IUP. Atau, selain itu memaksa semua perusahaan tambang batubara menggunakan angkutan PT. KAI tetapi belum memadai secara kapasitas sehingga perusahaan tambang batubara tidak memiliki bargaining power untuk melakukan negosiasi.

2. Faktanya walaupun semua pengangkutan batubara melewati jalan khusus milik PT. Titan Infra Energy (PT. Servo Lintas Raya) atau jalur kereta api milik PT. Kereta Api Indonesia maka tetap harus melewati sebagian jalan nasional yang seharusnya menjadi wewenang pemerintah pusat untuk mengaturnya. Seharusnya seluruh jalan umum tidak boleh digunakan, tetapi kenapa ada perlakuan khusus, bagi yang menggunakan jalan khusus PT. Titan Infra Energy (PT. Servo Lintas Raya) dan jalur PT KAI khusus dapat menggunakan jalan umum nasional ? Jika jalan umum dilarang untuk digunakan untuk kegiatan pengangkutan batubara dan wajib menggunakan jalan khusus.

Jika diberlakukannya Pasal 52 ayat (1) dan ayat (2) Perda Provinsi Sumsel No. 5/2011 dan Pergub Provinsi Sumsel No. 74/2018 beserta aturan turunanya maka akibat ekonominya berdampak kepada Perusahaan Batubara yang belum memiliki jalan khusus sendiri akan berhenti beroperasi sehingga akibat lebih lanjut akan terjadi pemutusan hubungan kerja (pengangguran), sopir dan truk pengangkut batubara menganggur, negara tidak menerima pendapatan royalty.

Berdasarkan data yang dihimpun dari berbagai sumber maka Pemerintah Provinsi Sumsel akan kehilangan pendapatan dari royalty sebesar US\$ 12 juta atau senilai dengan Rp 181 Miliar/tahun akibat berkurangnya 5 juta ton per tahun penjualan batubara Sumsel serta berkurangnya pendapatan devisa negara karena ekspor batubara terganggu.

\section{PENUTUP}

\section{A. Simpulan}

1. Adanya Ketentuan Pasal 52 ayat (1) dan (2) Perda Provinsi Sumsel yang melarang menggunakan seluruh jalan umum untuk kegiatan pengangkutan 
batubara bertentangan dengan norma undang-undang yang memberikan kewenangan kepada pemerintah pusat untuk mengatur jalan nasional bukan pemerintah daerah.

2. Berlakunya Perda Provinsi Sumsel tersebut telah menimbulkan implikasi hukum bagi pemegang ijin usaha pertambangan karena tidak dapat menggunakan jalam umum untuk kegiatan pertambangan padahal undangundang membolehkannya jikapun perda provinsi Sumsel hanya boleh mengatur larangan untuk jalan provinsi akan tetapi melarang seluruh jalan yang ada di Sumsel sehingga bagi pemegang ijin usaha pertambangan mengalami kerugian secara ekonomi karena dengan adanya larangan menggunakan jalam umum (wajib menggunakan jalan khusus) dan hanya ada satu jalan khusus milik perusahaan swasta sehingga memberikan peluang kepada pemilik jalan khusus untuk memonopoli yang berakibat pada adanya persaingan usaha tidak sehat.

\section{B. Saran}

1. Norma hukum perda provinsi Sumsel tidak boleh mengatur hal-hal yang bertentangan dengan norma hukum yang ada pada tingkat undang-undang sehingga norma tersebut menimbulkan dualisme hukum dalam penyelenggaraan pemerintahan di Provinsi Sumsel dan terlebih lagi norma perda provinsi tersebut secara hirarkis bertentangan dengan norma yang lebh tinggi sehingga mengakibatkan adanya ketidakpastian hukum bagi usaha pertambangan.

2. Adanya norma hukum dalam perda provinsi Sumsel yang bertentangan dengan norma hukum yang lebih tinggi maka langkah pencabutan atas norma hukum tersebut harus dilakukan oleh Pemerintah Provinsi Sumsel (Gubernur dan Dewan perwakilan daerah provinsi). Jikapun larangan kegiatan pengangkutan batubara menggunakan jalan umum (jalan nasional) maka larangan tersebut harus diatur oleh pemerintah pusat sebagai dengan kewenangannya bukan pemerintah daerah. 


\section{DAFTAR PUSTAKA}

\section{Peraturan perundang-undangan:}

Undang-undang Nomor 38 Tahun 2004 tentang Jalan

Undang-Undang Nomor 4 Tahun 2009 Tentang Pertambangan Mineral dan Batubara

UU Nomor 12 Tahun 2011 Tentang Pembentukan Peraturan Perundang-Undangan Peraturan Pemerintah Nomor 34 Tahun 2011 tentang Jalan

Peraturan Daerah Provinsi Sumatera Selatan Nomor 5 Tahun 2011 tentang Pelaksanaan Kegiatan Usaha Pertambangan Batubara

Peraturan Gubernur Sumatera Selatan Nomor 23 tahun 2012 tentang kegiatan pertambangan.

Peraturan Gubernur Sumatera Selatan Nomor 74 tahun 2018 tentang Pencabutan Peraturan Gubernur Sumatera Selatan Nomor 23 tahun 2012 tentang kegiatan pertambangan

Peraturan Menteri Pekerjaan Umum Nomor 11/PRT/M/2011 tentang Pedoman Penyelenggaraan Jalan Khusus

Peraturan Menteri Pekerjaan Umum nomor 20/PRT/M/2011 tentang pedoman pemanfaatan dan penggunaan bagian-bagian jalan

Peraturan Menteri Hukum dan HAM Nomor 32Tahun 2017 tentang Tata Cara Penyelesaian Sengketa Peraturan Perundang-undangan Melalui Jalur Nonlitigasi

Surat Edaran Gubernur Sumsel Nomor 041/SE/Dishubkominfo/2015 tentang Pengaturan Waktu Operasional Angkutan Batubara dan Kayu Log

Surat Edaran Gubernur Sumsel Nomor 540/2359/DESDM/2018 tanggal 6 November 2018 mengenai Angkutan Batubara

Surat Dinas Perhubungan Provinsi Sumatera Selatan Nomor 551.2/4151/5/Dishub tanggal 8 November 2018 mengenai Toleransi Angkutan Batubara.

Keputusan Menteri Pekerjaan Umum No. 631/KPTS/M/2009 tahun 2009 tentang Penetapan Ruas-Ruas Jalan Menurut Status Sebagai Jalan Nasional Menentukan Bahwa Lintas Jalan Palembang-Prabumulih-Muara EnimLahat Merupakan Jalan Nasional. 


\section{Jurnal:}

Tommy Putra Armada, Analisa Ekonomi Perbaikan Jalan Palembang - Betung Kab. Banyuasin Terhadap Nilai Kerugian Akibat Kemacetan, Jurnal Tehnik Sipil dan Lingkungan, Vol. 2 No. 3, September 2014

\section{Internet:}

https://balai3.wordpress.com/2011/07/01/alternatif-solusi-permasalahan-angkutanbatubara-di-sumatera-selatan/ (diakses pada tanggal 27 Desember 2018, Pukul $17.00 \mathrm{wib})$.

https://news.detik.com/berita/4291797/pengusaha-di-sumsel-setuju-truk-batu-barawajib-lewat-jalan-khusus (diakses pada tanggal 27 Desember 2018, Pukul $16.30 \mathrm{wib})$.

https://sumatra.bisnis.com/read/20181109/436/858105/angkutan-batu-bara-sumselbelum-ada-truk-melintas-di-jalan-khusus (diakses pada tanggal 27 Desember 2018, Pukul 16.30 wib).

https://sumatra.bisnis.com/read/20181109/436/858105/angkutan-batu-bara-sumselbelum-ada-truk-melintas-di-jalan-khusus (diakses pada tanggal 27 Desember 2018, Pukul 16.30 wib).

https://www.kompasiana.com/andre_darmawan/552c404e6ea834a1328b4580/menj erat-perusahaan-tambang-yang-menggunakan-jalan-umum-tanpa-izin (diakses pada tanggal 02 Januari 2019, Pukul 10.00 wib). 